\title{
The Role of Social Sciences and Humanities in Integrative Research on Natural Resources
}

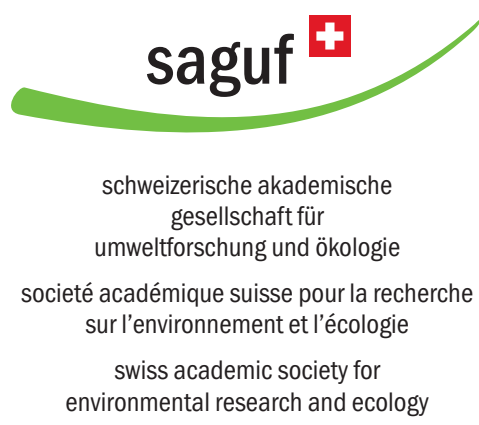

\author{
The saguf-working group Integrative Research on \\ Natural Resources (AG IRF) explores the character of \\ an integrative research on natural resources and the \\ preconditions for and possibilities of a better cooperation \\ between scientific domains.
}

Patrick Wäger, Olivier Ejderyan, Franziska Schmid, Michael Stauffacher, Claudia Zingerli

The Role of Social Sciences and Humanities in Integrative Research on Natural Resources

GAIA 23/2 (2014): 142-144 | Keywords: integrative research, natural resources, social sciences and humanities (SSH)

\begin{abstract}
Natural Resources and the Sciences
The growing global population with its rising demand for food, energy, and materials increases pressure on natural resources. Concurrently, questions regarding a more sustainable use of natural resources ${ }^{1}$ are becoming ever more important. Just like natural and engineering sciences, the social sciences and humanities ( $\mathrm{SSH}$ ) have great potential to tackle such issues, e. g., by informing debates related to social and environmental justice, local and regional conflicts, institutional frameworks, and the role of lifestyle, individual consumption and social innovation and transformation processes. However, with some exceptions, contributions of the SSH to a more sustainable use of natural resources appear to be scarce or lack visibility.
\end{abstract}

Contact authors: Dr. Patrick Wäger | Empa | Technology \& Society Laboratory | St. Gallen | Switzerland | E-Mail: patrick.waeger@empa.ch

Contact saguf: saguf Office | Dr. Claudia Zingerli | ETH Zurich D-USYS/CHN | 8092 Zurich | Switzerland | E-Mail: saguf@env.ethz.ch | www.saguf.ch

(C) 2014 P. Wäger et al.; licensee oekom verlag. This is an article distributed under the terms of the Creative Commons Attribution License (http://creativecommons.org/licenses/by/3.0), which permits unrestricted use, distribution, and reproduction in any medium, provided the original work is properly cited.
In 2012, saguf members founded the working group Integrative Research on Natural Resources ( $\mathrm{AG} \mathrm{IRF}^{2}$ ). The purpose of the AG IRF is to take up key questions related to the challenges of a more sustainable use of natural resources and to identify the roles of the scientific domains participating in this research. In particular, the AG IRF aims at exploring the topic from a broad systemic perspective and at providing both empirical and critical contributions regarding the interplay between natural and engineering sciences and the SSH. So far, the AG IRF has primarily worked towards three objectives: 1 . to explore the specific character of an "integrative" research on natural resources, 2 . to identify and foster the role of SSH in integrative research, 3. to clarify the preconditions and possibilities for a better integration of $\mathrm{SSH}$ with natural and engineering sciences. The AG IRF relates "integrative research" to an attitude of openness and engagement from researchers with different backgrounds.

A series of activities in 2012 and 2013 contributed to the exploration of the AG IRF's objectives. In particular, the AG IRF established an inventory of SSH research in Switzerland and organised two workshops, one with focus on the role of SSH, another with focus on the integrative character of research on natural resources.

\section{SSH in Switzerland}

The inventory of SSH research activities in Switzerland, carried out on behalf of the Swiss Academy of Humanities and Social Sciences (SAGW) in 2012, offered insights into the research topics and affiliations of scientists from the SSH engaged in research on a sustainable use of natural resources (Schmid and Stauffacher 2013). The inventory covered cantonal universities, the Federal Institutes of Technology ETH Zurich and EPFL, as well as the research institutes of the ETH domain ${ }^{3}$.

About 150 researchers affiliated to 60 institutes were identified based on various databases, websites and an online survey sent to $340 \mathrm{SSH}$ units. They represent disciplines such as geography, political sciences, and economics; SSH disciplines such as anthropology, sociology, psychology, or philosophy are hardly represented.

Researchers focusing on natural resources in a broad range of topics predominantly work in institutions of the ETH domain or in interdisciplinary centres at cantonal universities.

\footnotetext{
1 In German, we prefer the term "Umgang mit" ("doing with") to also allow for the option of not using natural resources.

2 www.irf.saguf.ch

3 www.ethrat.ch/en/node/595
} 
Session Swiss Geosciences Meeting 2014:

Drilling the Earth - Challenges for a Research Integrating Natural and Engineering Sciences with Social Sciences and Humanities

November 22, 2014, Fribourg

Organisation: AG IRF

We invite papers that 1 . engage with the rationales of integrative research on natural resources, 2. describe and evaluate integrative research projects, and 3. critically reflect on experiences of researchers engaged in integrative research projects on natural resources.

MORE INFORMATION:

- www.irf.saguf.ch

- www.geoscience-meeting.ch/2014

The inventory revealed vivid $\mathrm{SSH}$ research activities on natural resources in Switzerland. However, a thematic or institutional concentration cannot be identified. Especially cantonal universities and SSH disciplines like anthropology, sociology, psychology, or philosophy seem to lack a critical mass. In view of the complexity of problems it is vital that the SSH contribute to this field by addressing topics such as societal change, understanding of context or underlying rules and norms in sustainable use of natural resources. Therefore, ways need to be found to enable and strengthen $\mathrm{SSH}$ research on sustainable use of natural resources. From a researchmanagement perspective the question is how the SSH can effectively work with and collaborate on equal terms with the natural and engineering sciences on issues related to the use of natural resources.

\section{The Role of SSH in Research on Natural Resources}

On the occasion of the World Resources Forum (WRF) 2013 conference in Davos, the AG IRF members Michael Stauffacher, Patrick Wäger, and Claudia Zingerli ran a workshop on The Role of the Social Sciences and of the Humanities in Research on a More Sustainable Use of Natural Resources. ${ }^{4}$ The workshop opened with a presentation of the preliminary results of an online survey carried out by the AG IRF among the WRF 2013 participants from September 23 to October 1,2013 . The majority of the respon-

4 www.worldresourcesforum.org/wrf2013/ role-social-sciences-and-humanities dents partly or fully agreed that SSH are not (yet) well integrated into research on sustainable use of natural resources, and that there is a need for action in view of their better integration. According to a statistical analysis of the responses, three possible roles of SSH were distinguished: 1. codesigning research on natural resources and co-producing knowledge with natural and engineering scientists; 2 . translation and communication of findings to decision-makers and the public; and 3. critical reflection of methodological approaches and normative underpinnings of natural resource research.

The presentations by the invited speakers covered all three roles. The practical philosopher Anton Leist critically reviewed the ethical and normative dimension of the ecological footprint. Tobias Haller, a social anthropologist, uncovered the challenges in the collaboration between SSH and natural and engineering sciences: "We have to deal with different scientific tribes". Stefan Mann, an agro-economist, presented a successful example of integrative research: the integration of economics and ecology through modelling in the agricultural sector. Finally, a group of scientists engaged in interdisciplinary research on natural resources, Rainer Kündig, Jörg Matschullat, Otto Smrekar, and Wolfgang Stark, introduced an innovative programme bringing together science and the arts for tapping more into implicit and transcending knowledge.

In lively discussions, the participants confirmed the results of the survey and unveiled the diversity of contributions from SSH to an integrative research on a more sustainable use of natural resources.

saguf-Tagung 2014:
Zukunft gestalten:
Nachhaltigkeitskompetenzen
in der Hochschulbildung
26. November 2014, Zürich
Veranstalter: AG Bildung für
nachhaltige Entwicklung (AG BNE),
Sustainable Development at
Universities Programme.
WEITERE INFORMATIONEN:
www.bne.saguf.ch

\section{Integrative Research on Natural Resources}

With a half-day event on occasion of the saguf annual conference on November 27 , 2013, the AG IRF moved another step forward. The participants explored the possibilities and requirements of research on natural resources including SSH as well as natural and engineering sciences. They represented universities, ETH Zurich, universities of applied sciences, federal research institutions, public administration, private companies. The majority were either natural or social scientists, with a few participants from the humanities. The workshop moderated by Franziska Schmid and Claudia Zingerli aimed at creating a stimulating atmosphere and interaction among participants. Presentations alternated with world café discussions, group debates and open spaces for networking. Discussions covered issues like defining "natural resources" or "research on natural resources", identifying mutual expectations and needs as well as exploring possibilities of funding.

The workshop started with four inputs on personal experiences from different contexts of research on natural resources. Political scientist Eva Lieberherr from eawag and the University of Bern advocated not only for interdisciplinary research but also for a stronger involvement of practitioners and stakeholders to address questions and needs in Swiss water management. Geologist Rainer Kündig, executive manager of the Swiss Geotechnical Commission, pointed out the important but often neglected investments in coordination and facilitation processes between the parties, linking academia, research associations, authorities 
and the public. Paola de Coppi, a chemical engineer from the University of Applied Sciences Rapperswil, presented the concept of "material stewardship" that assigns shared responsibility to producers and users of materials. Consequently, a close cooperation between investigators, industrial partners, and national authorities is essential in research projects on natural resources. Social anthropologist Tobias Haller from the University of Bern focused on two aspects of his research: 1 . the reflection of concepts such as "nature" and "resources" in African cultures and the importance of local knowledge; 2 . the challenges of interdisciplinary work requiring awareness of and debates on different scientific approaches, methodologies and claims of "truth".

In world café discussions, participants dealt with three questions: 1 . What does integrative research on natural resources mean? 2. What are criteria and conditions for "good" integrative research? 3. What forms of collaboration and cooperation does integrative research require? The discussions revealed three main topics:

- Meaning and relevance of integrative research on natural resources: "Natural resources" is a contested concept, depending on the epistemological community, the disciplinary background, and the question of research. On the one hand, this hinders collaboration between researchers from different backgrounds, because a common understanding usually lacks. On the other hand, the concept's openness and the conceptual refinement required in each project and context allows the researchers to work together on relevant questions.

- Conditions and criteria of a well-established integrative research on natural resources: Requirements include personal qualities of individuals involved, such as mutual respect and trust, willingness to cooperate and communicate, readiness for experimentation, as well as long-term processes. These need institutional backup such as facilitation of research and reflection processes, and also a favourable system of funding and reputation. Structural and institutional change is required for research on natural resources.
- Forms of cooperation and collaboration: Collaboration between researchers from $\mathrm{SSH}$, natural and engineering sciences can be fostered by: understanding research as a common learning process that includes moderators and "border crossers"; creating spaces for interaction and debates; focusing on challenges of sustainable development and problemoriented research goals.

In the concluding plenary discussion, the diverse notions of "natural resources" reappeared as a key issue. The emphasis lied on open, research- and context-specific definitions to enable better integration of the $\mathrm{SSH}$ without reducing their role to communicating research findings only.

\section{Outlook}

A series of activities initiated and carried out by the saguf AG IRF brought together a network of scientists and practitioners dealing with questions of a more sustainable use of natural resources. This article reveals only parts of the rich material collected in the process. The AG IRF is working towards a deeper analysis and discussion. In typical saguf manner, the working group provides a platform for out-of-the box thinking and for creative exchange in a setting transcending institutional constraints. The AG IRF will go on presenting its work at events such as a session during the Swiss Geosciences Meeting of November 22, 2014, and will consolidate the inputs and data collected in a position paper.

So, stay tuned and be ready for further exchange and stimulating discussions!

The AG IRF is grateful for financial support by the Swiss Academy of Humanities and Social Sciences (SAGW) and the Swiss Academy of Sciences (SCNAT). We are thankful for exchange with the Swiss Society for African Studies (SSAS), particularly Tobias Haller, and the Swiss Society for Agricultural Economics and Rural Sociology (SSA), particularly Stefan Mann and Christian Schader, and our new colleagues in the AG IRF.

\section{References}

Schmid, F., M. Stauffacher. 2013. Nachhaltiger Umgang mit natürlichen Ressourcen sozial- und geisteswissenschaftliche Forschungslandschaft der universitären Hochschulen der Schweiz. Bern: Schweizerische Akademie der Geistes- und Sozialwissenschaften (SAGW).

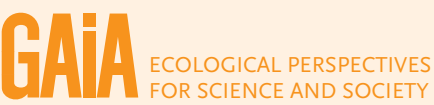

(C) 2014 Verein Gaia | Konstanz, St. Gallen, Zürich

IAUPTHERAUSGEBERIN

Verena Winiwarter Wien

(verantwortlich im Sinne des Presserechts)

REDAKTION

Dr. Almut Jödicke | ETH Zentrum

Postfach CAB $42 \mid 8092$ Zürich | Schweiz |

E-Mail: redgaia@env.ethz.ch

Dr. Martina Blum/Tobias Mickler | oekom verlag | Waltherstr. 2980337 München Deutschland E-Mail: blum@oekom.de/mickler@oekom.de

Dr. Ulrike Sehy | oekom verlag | Hagenbuchrain 13 8047 Zürich |Schweiz |E-Mail: sehy@oekom.ch

GRAFISCHE GESTALTUNG UND SATZ

Heike Tiller|München |E-Mail: h.tiller@freenet.de

VERLAC

oekom verlag - Gesellschaft für ökologische Kom munikation mbH | Waltherstr. 29| 80337 München Deutschland | www.oekom.de| Gesellschafter und Anteile: Jacob Radloff, Feldafing, 77 Prozent, und Christoph von Braun, München, 23 Prozent

ANZEIGEN

Tabea Köster (verantwortlich) | oekom GmbH | Tel.: +498954418425 | E-Mail: anzeigen@oekom.de

DRUCK

Kessler Druck + Medien 86399 Bobingen Deutschland www.kesslerdruck.de

Die Zeitschrift und alle ihre Inhalte sind urheberrechtlich geschützt. Jede Verwertung, die nicht ausdrücklich vom Urheberrechtsgesetz zugelas sen ist, bedarf der Zustimmung des Vereins Gaia. Namentlich gekennzeichnete Artikel müssen nich die Meinung der Herausgeber/Redaktion wiedergeben. Unverlangt eingesandte Manuskripte, für die keine Haftung übernommen wird, gelten als Veröffentlichungsvorschlo zu den Bedingungen Veroffentlichungsvorschlag zu den Bedingungen ginalarbeiten angenommen. Die Verfasser(innen) erklären sich mit einer nicht sinnentstellenden redaktionellen Bearbeitung einverstanden.

ERSCHEINUNGSWEISE Viermal im Jahr. BEZUGSBEDINGUNGEN

Probeabonnement (2 Ausgaben inkl. Versand, nur in Deutschland): 29,50 EUR | Jahresabonnement: 102,70 EUR für Privatpersonen; 185,20 EUR für Unternehmen, Institutionen, Bibliotheken; 69,35 EUR für Studierende, Auszubildende, Schüler(innen) (jährlicher Nachweis erforderlich) | Einzelheft 27,30 EUR. Alle Preise inkl. MwSt., zzgl. Porto- und Versandkosten. Abbestellungen sechs Wochen vor Ablauf des Abonnementjahres. Zahlungen im Voraus.

BESTELLUNG, ABOVERWALTUNG, VERTRIEB

InTime Media Services $\mathrm{GmbH}$ | Zeitschriften oekom Postfach 1363 82034 Deisenhofen|Deutschland Tel.: +498985853570| Fax: +49898585362570|

E-Mail: oekom@intime-media-services.de www.oekom.de/gaia/abonnement

KONTO für Deutschland: Postbank München BLZ 70010080 | Konto 358744803

für die Schweiz: PostFinance SWISS POST BLZ 30001101 | Konto 40-344357-9

ekom kompensiert bereits seit 2008 sein nvermeidlichen $\mathrm{CO}_{2}$-Emissionen.

\section{ClimatePartner $^{\circ}$}

\section{ISSN 0940-5550}

Gedruckt auf Circle-

silk Premium Whit

$100 \%$ Recycling
von Arjo Wiggins

Igepagroup. 